\title{
Editorial
}

\section{Las apropiaciones académicas y los indicadores de impacto}

Un debate en plena discusión en Iberoamérica es el papel de las apropiaciones del conocimiento científico y los indicadores para medir su impacto. En primer término distinguiré entre lo que llamo apropiación académica del conocimiento y lo que diversos autores han llamado apropiaciones sociales del conocimiento. La primera tiene que ver con las prácticas de comunicación y transferencia de conocimiento de las comunidades científicas y lo segundo tiene que ver con las múltiples formas en que el conocimiento va a la sociedad. Esta editorial se aproximará a la apropiación académica.

Las apropiaciones académicas se encuentran en varios niveles: el primero el que hacen colegas (pares) que utilizan este conocimiento y como indicador del uso se encuentran las citaciones. Este indicador es muy sensible y por tanto vulnerable a las dinámicas de citación de las comunidades académicas. Por ejemplo, las comunidades con poco uso de su conocimiento suelen ser endogámicas ${ }^{1}$ y con baja colaboración internacional, también se caracterizan por no modificar fácilmente sus hábitos de citación.

En este sentido, una parte de estas citas suelen auto-invisibilizarse, esto es, no reconocer sus propios esfuerzos y los de los grupos de pares locales (regionales) y son paradójicos -en el sentido negativo- aun cuando se proclaman en un discurso

1 El término se utiliza para denotar un sistema académico cerrado y limitado de conocimiento que rechaza, intencionalmente o por desactualización, aportes de otras comunidades cercanas o externas. anti-corriente principal de la ciencia. Al mismo tiempo, desprecian la producción propia o la producción regional y fundamentan su trabajo en la producción que dicen superar.

Por otro lado, los grupos de investigación con una producción importante pueden subir y bajar la visibilidad de otros grupos y de las revistas pues la cantidad de trabajo termina además concentrando citas en algunos trabajos o revistas particulares y en esa medida se afectan las medidas derivadas de los impactos expresados en citas.

En este sentido,y como una respuesta que buscaría tener elementos adicionales para la evaluación de producción académica, es recomendable: 1. usar el cuartil donde se encuentra la revista pues da una idea más precisa de la dinámica de la misma y además muestra la revista en relación con otras revistas con su margen de variabilidad en ese rango. 2. Usar y contrastar indicadores diversos de los distintos sistemas de información (ISI-SCOPUS, por ejemplo). En este sentido, un indicador que normalice las citas en relación con el área y con las fuentes de donde provienen las citas resulta ser un indicador más informativo de las dinámicas de impacto de la visibilidad de ese conocimiento. 3 . Toda lectura de indicadores debe tomar en cuenta la historia de la revista; la cantidad de contenidos y en especial la cantidad de contenidos incluidos en las bases de datos; el lugar de origen de la revista; si la revista se edita por una empresa transnacional o por una universidad y en qué región del mundo 
se encuentra; y si el contenido de la revista está o no en acceso abierto ${ }^{2}$ entre otros temas.

Es claro que hacer una lectura simplista de indicadores no es suficiente para dar cuenta de la dinámica de incidencia de los contenidos de una revista, sin embargo, la complejidad de los sistemas de información y los indicadores de los que hoy disponemos nos permiten dar cuenta de ámbitos que antes no podíamos evidenciar.

Es evidente también que la mayor parte de las comunidades que producen conocimiento buscan, y no en forma ingenua, incidir en la comunicación y en la apropiación de otros académicos. Pero esta apropiación no es la única forma y las piezas de comunicación hoy permiten desarrollar diversos canales para incidir en múltiples formas en estas comunidades. Un impacto que resulta muy interesante es, por ejemplo, el que resulta del uso de comunidades académicas en formación tanto en el pregrado como en el postgrado o el de comunidades profesionales que se mueven más en el ámbito aplicado y estas incidencias no se ven seguramente en indicadores de citación si no, por ejemplo, en los usos que en los currículos se hacen de estos contenidos o en los usos que hacen los profesionales de los contenidos académicos en sus prácticas cotidianas. Por lo tanto, estos indicadores son más difíciles de encontrar, evaluar y recabar, sin embargo, resultan fundamentales para dar cuenta de otras apropiaciones académicas.

\section{WILSON LÓPEZ LOPEZ} EDITOR

2 El sistema denominado Open Acces. 


\section{Editorial}

\section{Academic appropriation and Impact Indicators}

The role of appropriation of scientific knowledge and the indicators designed to measure its impact is being hotly debated in Iberoamerica right now. I will separate what I call academic appropriation of knowledge from what many authors have called social appropriation of knowledge. The former is related to knowledge communication and transference practices in scientific communities, and the latter has to do with the multiple ways in which knowledge goes to society. This editorial will address academic appropriation.

Academic appropriations are found in many levels: the first is that performed by colleagues (peers) who use this knowledge, and citations are the indicators of usage. This is a sensitive indicator, and thus vulnerable to citation dynamics in academic communities. For example, communities with low levels of knowledge use are generally endogamic and have low international collaboration. They are also characterised by not easily modifying their citation habits.

In this sense, a part of these citations generally make themselves invisible, this is, they do not acknowledge neither their own efforts, not those made by local peer groups (regional), and are negatively paradoxical, even when proclaimed in an anti-mainstream science discourse. At the same time, they downplay their own production or the regional production, and ground their work on the production that they claim to go beyond.

On the other hand, research groups with an important output can improve or decrease the visibility of other groups and journals, since the amount of work ends up concentrating citations in particular works or journals, which affects the measures derived from citation-expressed impacts.

In this sense, and as a response with additional elements for assessing academic production, it is suggested that: 1 . The quartile of the journal be used, since it gives a more accurate idea of its dynamics and shows the journal in relation to other journals with its variability margin in that range. 2. Use and contrast diverse indicators provided by the different information systems (ISI-SCOPUS, for example). In this sense, an indicator that normalises citations with regards to area and citation sources is a more informative indicator of the impact dynamics for that knowledge. 3. Every reading of the indicators must take into account the journal's history, the amount of contents, and specially the amount of contents included in databases; the journal's place of origin; whether the journal is edited by a transnational company or a university; the journal's region of the world; and whether or not it is open access, amongst others.

It is clear that a simplistic reading of indicators is not enough to account for a journal's content incidence dynamics; nevertheless, the complexity of information systems and the indicators available to us today can account for things we could not account for previously.

Evidently, most knowledge-producing communities aim to, and not naively, have an influence on the communication and appropriation of other researchers. But this appropriation is not the only way, and communication pieces allow us today to 
develop different channels in order to have an influence on these communities, in many ways. A very interesting impact would be, for example, the one that results from the use of academic communities in training, both undergraduate and postgraduate, or professional communities that operate in the applied settings. These influences are surely not translated into citation indicators, but, for example, in the uses made by curricula, or the uses made by professionals of academic contents in their daily practices. Hence, these indicators are harder to find, assess and gather, despite being important in order to account for other academic appropriations.

WILSON LÓPEZ LOPEZ EDITOR 